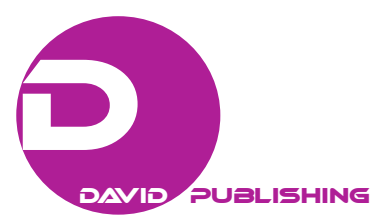

\title{
Process Management in Insurance Companies
}

\author{
Lech Gąsiorkiewicz, Marta Kruk \\ Warsaw University of Technology, Warsaw, Poland
}

\begin{abstract}
The importance of insurance activity is constantly growing, generating new problems and setting new challenges. One of these challenges is to meet the growing requirements and expectations of customers. This requires the efficient management of insurance companies. This means the necessity of applying modern management concepts, first and foremost, the concept of process management and instruments related to this process. This article describes the results of research on process management in insurance companies operating in Poland that was conducted by the Faculty of Management at the Warsaw University of Technology and presents the concept of the identification of processes carried out in insurance companies encompassing management, basic and auxiliary processes, as well as the objectives of the processes and the relationships between the basic processes and other processes carried out in insurance companies.
\end{abstract}

Keywords: management of processes, process management, process identification of insurance activities, goals of process implementation, relationships between processes

\section{Introduction}

Insurance companies (like other financial institutions) operate in a changing environment. An increase in customer expectations in the area of new insurance products can be observed. Customers have become more and more assertive and expect the highest quality, even for traditional products. Higher customer requirements are directed to insurance companies in the field of insurance claims handling. Significant changes are also occurring on the financial markets where insurance companies conduct investment activities.

A condition for occupying the appropriate position in the modern economy and for increasing the level of the security of functioning in a competitive market is the introduction of new system solutions in the management of organizations. According to Trocki (2014), two approaches in management stand out-the functional and the procedural approaches. The functional approach places fixed aspects and the functional harmonization of activities at the forefront and puts emphasis on achieving the organization's goals. The process approach focuses on dynamic aspects and on the process harmonization of activities and emphasizes the satisfaction of the needs of the organization's clients. These approaches do not constitute alternative choices but rather complement each other. The increase in interest in the process approach that is expressed both by academia and through actual practice results from the growing need to satisfy the requirements and expectations of clients (Trocki, 2014).

Lech Gąsiorkiewicz, D. Sc., professor, Faculty of Management, Warsaw University of Technology, Warsaw, Poland.

Marta Kruk, Ph.D., lecturer, Faculty of Management, Warsaw University of Technology, Warsaw, Poland.

Correspondence concerning this article should be addressed to Lech Gąsiorkiewicz, ul. Narbutta 85, 02-524 Warsaw, Poland. 
In practice, one can meet two concepts, namely the management of processes and process management. Process management is a broader term consistent with the concept of a process approach, since the management of processes refers to selected processes and takes place also in organizations that are based on a functional approach. Process management is management in accordance with a process orientation and a process approach.

The development of process management, of its foundation of "principles, methods, and solutions" resulted in its differentiation and its becoming a new field of management. Process management is a response to the growing turbulence of the external and internal environments of enterprises, to the increased complexity of external and internal processes, to the individualization of customer needs and expectations, to short product life cycles, and to increases in the importance of intangible assets in creating a competitive advantage. The process approach is included in the sphere of contemporary management trends that promote decentralization, customer orientation, reorientation of the organizational structure from the vertical to the horizontal, and the cross-functional characteristic of the problem matter of enterprise management, all of which contribute to the efficiency of an organization in changing conditions (Trocki, 2010).

According to Nanz (2012), process management is a concept used in most modern enterprises in which functionally (vertically) divided activities are integrated.

The aim of this article is to seek answers to the following research questions:

- What are the experiences of Polish insurance companies in the field of process management?

- How can one present the process identification of an insurance activity?

The content contained in this publication applies to property life insurance companies, and certain fragments of it may also apply to life insurance companies.

\section{Process Management in Insurance Companies Operating in Poland}

There are 33 non-life (other personal and property) insurance companies on the Polish market (Polish Financial Supervision Authority, 2018), with 24 insurance companies operating in the form of a joint-stock company and nine insurance companies in the form of a mutual insurance company. The research was carried out in property insurance companies operating in the form of joint-stock companies. Out of 24 property insurers contacted in the matter of completing the survey questionnaire, 21 responded positively, which constitutes $87.5 \%$ of the surveyed population.

The first question in the questionnaire was: Is the concept of the management of processes used in the insurance company? The obtained answers are illustrated in Figure 1.

All insurance companies recognized that the application of the management of processes concept is now necessary; however, no insurance company has implemented it for all processes carried out in insurance companies. Of the 21 insurance companies that responded to this question, 18 companies, that is $85.7 \%$ of those questioned, implemented the management of processes in relation to selected processes, and three insurance companies, that is, in $14.3 \%$, intend to implement process management in the coming years. At the same time, it should be positively assessed that none of the respondents questioned the usefulness of the management of processes in insurance companies.

Further questions were addressed to insurance companies that implemented the management of processes in relation to selected processes. Eighteen insurance companies answered these questions. The structure of insurance companies according to the level of maturity of the implemented processes is shown in Figure 2. 


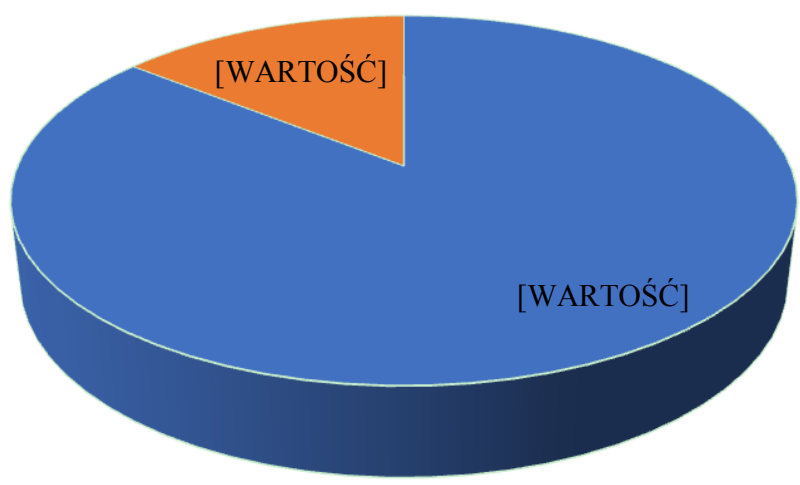

- Management of processes introduced in reference to selected processes

- The management of processes will be introduced within several years

Figure 1. Using the concept of the management of processes in insurance companies. (Source: Kruk, 2018).

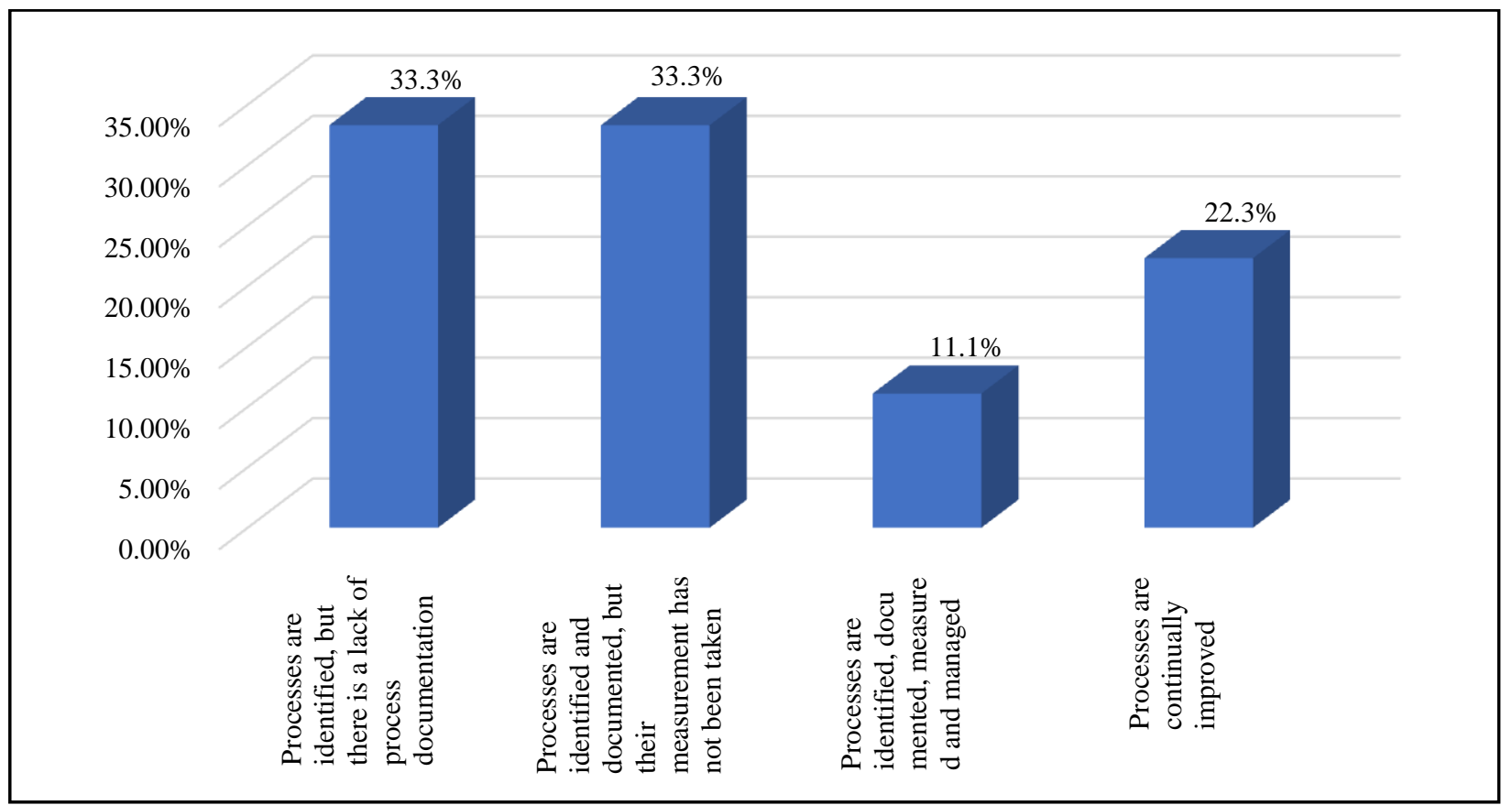

Figure 2. The structure of insurance companies according to the level of maturity of the implemented processes.

(Source: Kruk, 2018).

The level of process maturity in the examined insurance companies is very differentiated; however, there is no insurance company in which no processes have been identified. The conducted research shows that out of 18 insurance companies that declared that they apply management of processes, in six firms, i.e., 33.3\% processes are identified, but no procedural documentation is available. In six firms, i.e., $33.3 \%$ processes are identified and documented, but they are not measured. In two insurance companies, i.e., $11.1 \%$ processes are identified, documented, measured, and managed. In four insurance companies, i.e., $22.3 \%$ processes are undergoing continuous improvement. 
The next question concerned the reasons for implementing the concept of the management of processes in an insurance company. Respondents could choose no more than three answers. The reasons for implementing the concept of the management of processes in insurance companies are presented in Table 1.

Table 1

Reasons for Implementing the Concept of the Management of Processes in Insurance Companies

\begin{tabular}{lll}
\hline Reasons for implementing the concept of the management of processes & $\begin{array}{l}\text { Amount of } \\
\text { answers }\end{array}$ & Percentage (\%) \\
\hline Improving competitiveness & 2 & 11.1 \\
The ability to respond faster to the needs and expectations of customers & 9 & 50.0 \\
Improving the ability to respond faster to changes in the market & 5 & 27.7 \\
Increased flexibility of the insurance company & 1 & 38.9 \\
The need to improve existing products, create new products & 8 & 5.6 \\
Reducing costs, improving productivity & 1 & 44.4 \\
Implementation of an IT system & 5.6 & 5
\end{tabular}

Note. Source: Kruk (2018).

Respondents most often indicated that the most important reasons for implementing the process management concept were: the ability to respond faster to customer needs and expectations $(50.0 \%)$, to reduce costs and improve productivity (44.4\%), and to increase the flexibility of the insurance company (38.9\%). Another important reason was the improvement of the ability to react faster to changes occurring in the environment of the insurer (27.7\%). To a small extent, reasons for the implementation of process management were: the improvement of the competitiveness of the insurance company (11.1\%), the implementation of an IT system $(5.6 \%)$, or the need to improve existing products and to create new products $(5.6 \%)$.

The benefits observed in insurance companies after the implementation of the management of processes are indicated by the answers to the fifth question (see Table 2).

Table 2

Benefits of Implementing the Concept of the Management of Processes in Insurance Companies

\begin{tabular}{lll}
\hline Benefits from implementing process management & Amount of answers & Percentage (\%) \\
\hline Reducing the operating costs of the insurance company & 3 & 16.7 \\
Reducing the costs of on-going processes & 6 & 33.4 \\
Increased the efficiency of the insurance company operation & 7 & 38.9 \\
Faster response to customer needs and expectations & 9 & 50.0 \\
Improving the competitiveness of the insurance company on the market & 2 & 11.1 \\
Increasing the flexibility of the insurance company & 4 & 22.2 \\
Improving cooperation with external and internal clients & 6 & 33.4 \\
Increased work efficiency & 2 & 22.2 \\
Simplification of processes in the insurance company & 9 & 50.0 \\
Improving communication within the insurance company & 3 & 16.7
\end{tabular}

Note. Source: Kruk (2018).

Previous experience related to the implementation of the management of processes in Polish insurance companies indicates that these entities have obtained significant benefits in this respect. The implementation of the management of processes allowed for the simplification of processes in 50.0\% of insurance companies. The 
implementation of the management of processes allowed for a faster response to customer needs in $50.0 \%$ of surveyed insurance companies and contributed to increasing the efficiency of functioning of $38.9 \%$ of insurance companies. An equally high percentage of insurance companies, that is, $33.4 \%$ declared a reduction in the costs of on-going processes. The implementation of process management translated into better cooperation with internal and external clients in $33.4 \%$ of the insurance companies under examination, an increased flexibility of the insurance company in $22.2 \%$ of insurance companies and an increase in work efficiency in $22.2 \%$ of insurance companies. A smaller impact was indicated in the case of the reduction in the operating costs of insurance companies (16.7\%) and the improvement of communication within the insurance company (16.7\%). The reason for this may be the implementation of the management of processes in relation to only selected processes and not for the entire insurance company. A small percentage of insurance companies declared improved competitiveness on the market (11.1\%).

The implementation of the management of processes in the surveyed insurance companies, apart from the benefits indicated above, faces a number of barriers. The barriers related to the management of processes in insurance companies are presented in Table 3.

Table 3

Barriers to the Management of Processes in Insurance Companies

\begin{tabular}{lll}
\hline Barriers related to the management of processes & Amount of answers & Percentage (\%) \\
\hline Difficulties in understanding and applying process management & 12 & 66.7 \\
Difficulties in changing employee attitudes & 9 & 50.0 \\
Resistance of employees against continuous changes & 11 & 61.1 \\
No expected effects in the form of the expected increase in the efficiency of processes & 2 & 11.1 \\
Difficulties in understanding the new manner of functioning of the insurance company & 5 & 27.8 \\
Difficulties in the field of information systems supporting process management & 8 & 44.4
\end{tabular}

Note. Source: Kruk (2018).

Research conducted in this area in Polish insurance companies indicated that the biggest barriers to the implementation of process management were: difficulties in understanding and applying process management (66.7\%), resistance of employees against continuous changes $(61.1 \%)$, and difficulties related to changes in employees' attitude (50.0\%). In addition, $44.4 \%$ of respondents indicate difficulties resulting from the IT systems supporting the management of processes that insurers have at their disposal. The percentage of 27.8 of respondents indicated problems resulting from the understanding of the new functioning of the insurance company. A small percentage of respondents, i.e., $11.1 \%$, indicate the lack of expected effects in the form of the expected increase in the efficiency of processes.

\section{The Concept of the Identification of Processes Carried out in Insurance Companies}

The stages of the management of processes and of process management according to different authors are presented in Table 4.

As results from Table 4, the identification of processes of activities carried out in the organizational unit and their appropriate qualification is one of the first stages of the implementation of the process orientation. The identification consists in determining what processes are carried out in the enterprise, the division of activities performed within particular processes and the relations between processes. 
Table 4

The Stages of Process Management and of the Management of Processes

\begin{tabular}{|c|c|}
\hline Authors & Stages of the management of processes \\
\hline Netjes, Reijers, \& Van der Aalst, 2006 & $\begin{array}{l}\text {-process design } \\
\text {-configuration of processes } \\
\text {-execution of processes } \\
\text {-process control } \\
\text {-diagnosis of processes }\end{array}$ \\
\hline Zur Muehlen \& Ho, 2006 & $\begin{array}{l}\text {-specification of objectives and analysis of processes } \\
\text {-process design } \\
\text {-implementation of processes } \\
\text {-process monitoring } \\
\text {-process evaluation }\end{array}$ \\
\hline Nowosielski, 2008 & $\begin{array}{l}\text {-process identification } \\
\text {-process modelling } \\
\text {-introduction of processes } \\
\text {-the management of processes and the evaluation of their functioning }\end{array}$ \\
\hline Hallerbach, Bauer, \& Reichert, 2008 & $\begin{array}{l}\text {-process modelling } \\
\text {-selection of processes } \\
\text {-implementation and monitoring of processes } \\
\text {-process optimization }\end{array}$ \\
\hline Verma, 2009 & $\begin{array}{l}\text {-defining the goal } \\
\text {-identification of the process } \\
\text {-classification of the process } \\
\text {-definition of tools and the implementation process } \\
\text {-process monitoring }\end{array}$ \\
\hline $\begin{array}{l}\text { Dumas, La Rosa, Mendling, \& Reijers, } \\
2013\end{array}$ & $\begin{array}{l}\text {-process identification } \\
\text {-discovering processes } \\
\text {-process analysis } \\
\text {-process design } \\
\text {-implementation of processes } \\
\text {-monitoring and controlling processes }\end{array}$ \\
\hline Authors & Stages of process management \\
\hline Talwar, 1993 & $\begin{array}{l}\text {-defining the organization's strategy } \\
\text {-gaining and developing such competences and skills of organizations that are } \\
\text { necessary for the effective implementation of the strategy } \\
\text {-the design of basic processes supporting the development and use of the } \\
\text { organization's competences } \\
\text {-implementation of the process structure }\end{array}$ \\
\hline Houy, Fettke, \& Loos, 2010 & $\begin{array}{l}\text {-development of strategies in the field of the management of processes } \\
\text {-definition and modelling of processes } \\
\text {-implementation of processes in the organization } \\
\text {-realization of the implemented processes } \\
\text {-monitoring and controlling the implementation of processes } \\
\text {-optimization and improvement of processes }\end{array}$ \\
\hline Rummler \& Brache, 2010 & $\begin{array}{l}\text {-formulation of the strategy } \\
\text {-description and analysis of the current organization } \\
\text {-description and analysis of currently operating processes } \\
\text {-preparation of a process map and their method of measure } \\
\text {-designing the organizational structure } \\
\text {-preparation of the description of each function in the structure } \\
\text {-preparation of job descriptions } \\
\text {-designing a worker efficiency system for every work position } \\
\text {-introduction of management processes }\end{array}$ \\
\hline
\end{tabular}

Note. Source: Bitkowska (2019). 
The activity of insurance companies, like other organizations operating in a competitive market, is focused on customer needs and satisfaction, as illustrated in Figure 3.

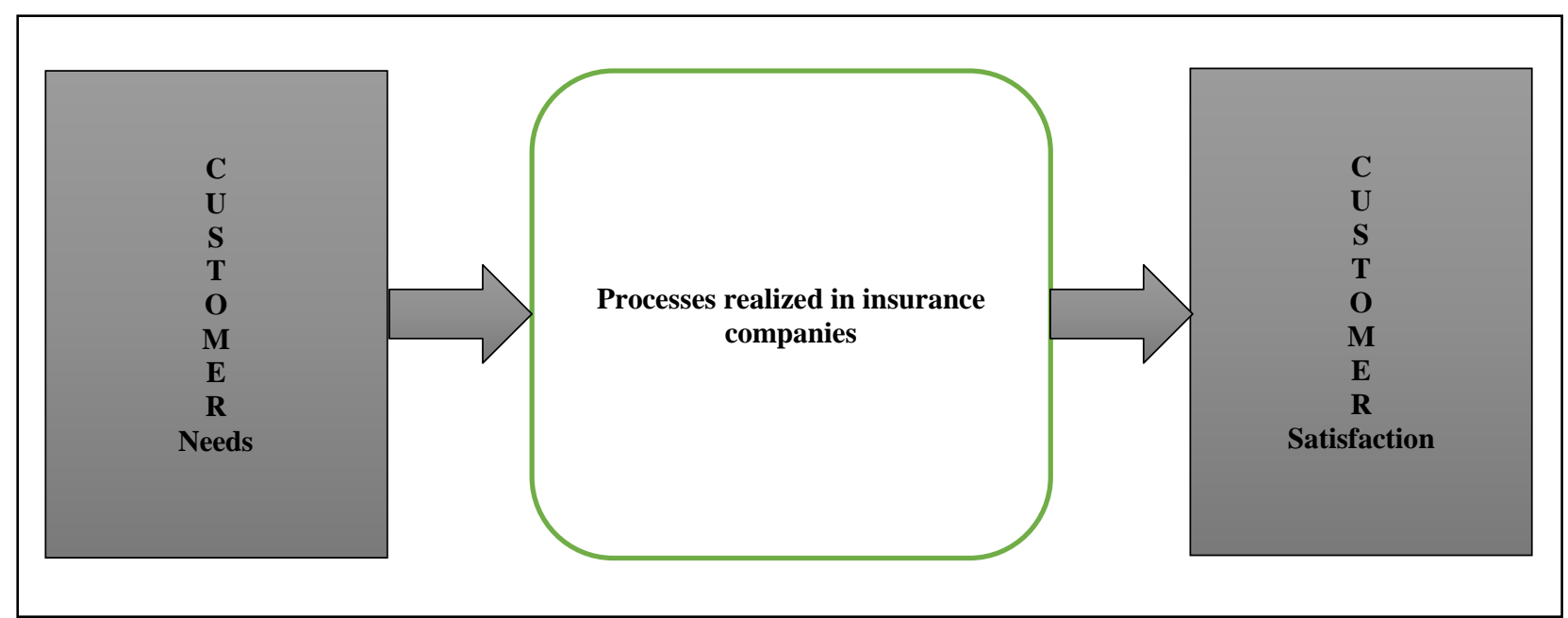

Figure 3. Market orientation of insurance companies. (Source: proprietary work).

The concept of the identification of insurance business processes and relations between basic processes and other processes carried out in insurance companies is presented in Figure 4.

Relations between basic processes and other processes carried out in insurance companies are bi-directional. Basic processes support management and auxiliary processes (continuous lines in Figure 4) while management and auxiliary processes support basic processes (dashed lines in Figure 4).

The concept of identifying the processes of insurance activity presented above seems to be an exhaustive array that takes into account current legal regulations; nevertheless the changing legal and institutional environment will force its change and supplementation. At the level of specific applications, this array should be adapted to the specific circumstances of its implementation.

In identifying the processes, three managing activity groups were identified: management processes, basic processes, and auxiliary processes. Management processes play a supervisory role over other processes. They give direction to the efficient operation of the whole insurance company by managing its activities; they define management policies and objectives. Basic processes are processes that directly bring added value to the insurance company and to the client; they provide a service to an external customer. These are processes that directly affect the image and market situation of an insurance company. Auxiliary processes are processes supporting basic processes. They do not directly create added value and are mainly aimed at internal customers.

The identification of insurance business processes requires defining the objectives of individual processes. The objectives of the implementation of separate insurance business processes are presented in Table 5. 


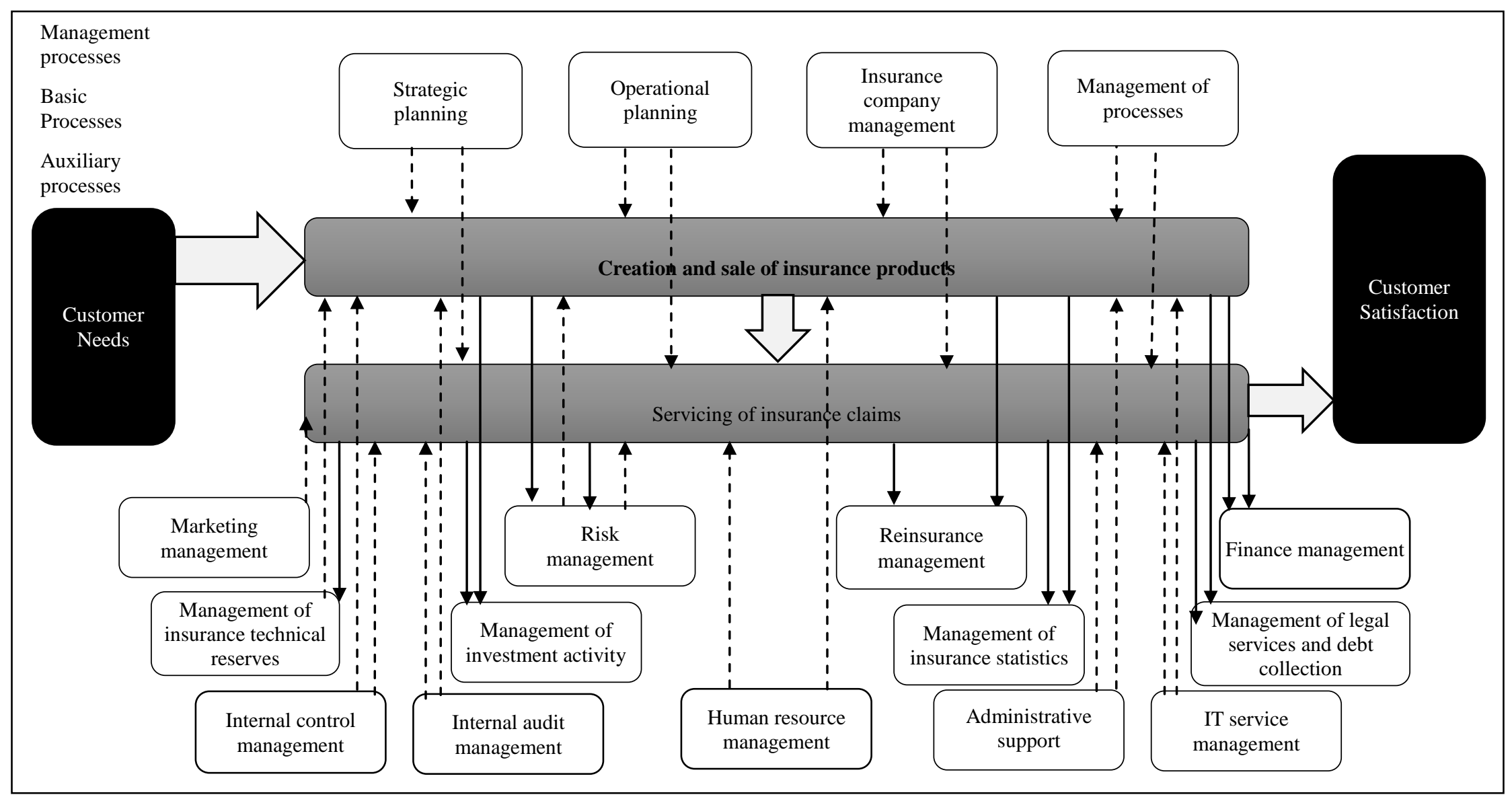

Figure 4. The concept of the identification of insurance business processes and relations between basic processes and other processes carried out in insurance companies. (Source: proprietary work on the basis of Gąsiorkiewicz, 2019). 
Table 5

The Objectives of the Implementation of Separate Insurance Business Processes

\begin{tabular}{|c|c|c|}
\hline Process group & Process & Objective \\
\hline \multirow{4}{*}{$\begin{array}{l}\text { Management } \\
\text { processes }\end{array}$} & Strategic planning & $\begin{array}{l}\text { Development of the insurance company's mission and strategic } \\
\text { activities related to its implementation. }\end{array}$ \\
\hline & Operational planning & $\begin{array}{l}\text { Development of short-term plans for the implementation of the } \\
\text { insurance company strategy. }\end{array}$ \\
\hline & Insurance company management & $\begin{array}{l}\text { Supervision of activities in the framework of individual processes } \\
\text { and the preparation of analyses and reports for insurance company } \\
\text { owners. }\end{array}$ \\
\hline & Management of processes & Modelling processes, researching of and evaluation of processes. \\
\hline \multirow[t]{2}{*}{ Basic processes } & $\begin{array}{l}\text { Creation and sale of insurance } \\
\text { products }\end{array}$ & $\begin{array}{l}\text { Acquiring (with the support of marketing activities) premiums in line } \\
\text { with the sales level and sales structure assumed in the insurance } \\
\text { company strategy. }\end{array}$ \\
\hline & Support for insurance claims & $\begin{array}{l}\text { Accepting damage claims related to concluded insurance contracts } \\
\text { and ensuring the efficient and timely processing of insurance claims. }\end{array}$ \\
\hline \multirow{13}{*}{ Auxiliary processes } & Marketing management & $\begin{array}{l}\text { Conducting activities supporting the sale of insurance products and } \\
\text { the shaping of the desired image of the insurance company. }\end{array}$ \\
\hline & Risk management & $\begin{array}{l}\text { Identification of risks occurring in the insurance company, } \\
\text { measurement of risks, analysis of interdependencies between risks, } \\
\text { drawing up reports on risks. }\end{array}$ \\
\hline & Reinsurance management & $\begin{array}{l}\text { Ensuring the financial security of an insurance company by } \\
\text { disbursing insurance risk, increasing insurance capacity, stabilizing } \\
\text { financial results, and protecting against catastrophic risks. }\end{array}$ \\
\hline & Finance management & $\begin{array}{l}\text { Ensuring an efficient accounting service (correctness and reliability } \\
\text { of data, correctness of registration of economic events, control of } \\
\text { costs incurred, payroll services, settlement of receivables and } \\
\text { liabilities, etc.), management of financial liquidity, solvency, equity } \\
\text { and the preparation of financial statements. }\end{array}$ \\
\hline & $\begin{array}{l}\text { Management of technical and } \\
\text { insurance reserves }\end{array}$ & $\begin{array}{l}\text { Creating and valuation of technical and insurance reserves for } \\
\text { solvency and reporting purposes. }\end{array}$ \\
\hline & Investment activity management & $\begin{array}{l}\text { Analysis of investment opportunities, creating a portfolio of } \\
\text { investments, valuation of investments, creating reports on investment } \\
\text { activities necessary for the needs of monitoring financial liquidity } \\
\text { and the solvency of the insurance company. }\end{array}$ \\
\hline & $\begin{array}{l}\text { Management of sets of insurance } \\
\text { statistics }\end{array}$ & $\begin{array}{l}\text { Collection of statistical data, their processing and making available to } \\
\text { authorized users. }\end{array}$ \\
\hline & $\begin{array}{l}\text { Management of legal servicing and } \\
\text { debt collection }\end{array}$ & $\begin{array}{l}\text { Preparation of legal opinions, conducting court and administrative } \\
\text { proceedings, ensuring proper legal protection of the insurance } \\
\text { company's interests, ensuring insurance contracts that are legally and } \\
\text { formally correct, and executing debt collection proceedings. }\end{array}$ \\
\hline & Internal control management & $\begin{array}{l}\text { Development of control procedures, implementation of periodic } \\
\text { inspections of individual areas of the insurance company's } \\
\text { operations, supervision over the implementation of post-control } \\
\text { recommendations. }\end{array}$ \\
\hline & Internal audit management & $\begin{array}{l}\text { Assessment of the adequacy and effectiveness of the risk } \\
\text { management system, the internal control system and management } \\
\text { systems. }\end{array}$ \\
\hline & Human resource Management & $\begin{array}{l}\text { Conducting matters related to employment, promotion, and dismissal } \\
\text { of employees, their professional development and the keeping of } \\
\text { employee personnel files. }\end{array}$ \\
\hline & $\begin{array}{l}\text { Management of administrative } \\
\text { support }\end{array}$ & $\begin{array}{l}\text { Providing rational technical infrastructure for the needs of the } \\
\text { processes being carried out, supplying office materials, managing } \\
\text { strict accountancy documents and managing the flow of } \\
\text { correspondence. }\end{array}$ \\
\hline & IT service management & $\begin{array}{l}\text { Analysis of needs and implementation of IT system projects, } \\
\text { activities in the field of maintenance and continuity of IT systems, } \\
\text { ensuring IT security. }\end{array}$ \\
\hline
\end{tabular}

Note. Source: proprietary work. 


\section{Conclusions}

The research results presented in the article indicate that insurance companies operating in Poland appreciate the need to seek new management solutions, among which process management plays an important role. Previous solutions in this area concerned the management of selected processes and not the entirety of processes undertaken in insurance companies. Therefore, conducting work in the field of process management in insurance companies is deliberate and fully justified. The starting point for implementing process management is the process identification of the process activity, the concept of which is presented in the article. The authors express hope that the presented concept will be the subject of further studies and research as well as scientific discussions.

\section{References}

Bitkowska, A. (2019). From classic to integrated process management in organizations. Warsaw: Publishing C. H. Beck.

Dumas, M., La Rosa, M., Mendling, J., \& Reijers, H. (2013). Fundamentals of business process management. Berlin: Springer.

Gąsiorkiewicz, L. (2019). The process architecture of the insurance business. Journal of Business and Economic Development, 4(2), 44-52. doi: 10.11648/j.jbed.20190402.12

Hallerbach, A., Bauer, T., \& Reichert, M. (2008). Managing process variants in the process life cycle. Proceedings of the Tenth International Conference on Enterprise Information Systems (ICEIS), June 12-16, Barcelona, Spain.

Houy, C., Fettke, P., \& Loos, P. (2010). Empirical research in business process management-Analysis of an emerging field of research. Business Process Management Journal, 16(4), 619-661.

Kruk, M. (2018). Cost management in insurance companies from a process management point of view. Warsaw: Faculty of Management, Warsaw University of Technology.

Nanz, G. (2012). Prozess-Alignment. Zeitschrift Fuhrung und Organisation (ZFO), (3), 210-212.

Netjes, M., Reijers, H., \& Van der Aalst, W. P. (2006). Supporting the BPM life-Cycle with FileNet. Proceedings of the Workshop on Exploring Modelling Methods for Systems Analysis and Design (EMMSAD), June 16-17, Montpellier, France.

Nowosielski, S. (2008). Logistics processes and projects. Wrocław: Publishing House of the Wrocław University of Economics. Polish Financial Supervision Authority. (2018). Retrieved 18.03.2018 from http://www.knf.gov.pl

Rummler, G. A., \& Brache, A. P. (2010). Increasing the efficiency of the organization. Warsaw: Polish Economics Publishing. Talwar, R. (1993). Business reengineering: A strategy-driven approach. Long Range Planning, 26(6), 22-40

Trocki, M. (2010). The process approach in management. Warsaw: Publishing House of the Warsaw School of Economics. Trocki, M. (2014). Project organization. Warsaw: Polish Economics Publishing.

Verma, N. (2009). Business process management: Profiting from process. New Delhi: Global India.

Zur Muehlen, M., \& Ho, D. T. Y. (2006). Risk management in the BPM life cycle. In Business process management workshops (pp. 454-466). Berlin Heidelberg: Springer. 